\title{
PENGARUH PANDEMI COVID-19 TERHADAP EFEKTIVITAS PEMBELAJARAN JARAK JAUH
}

\author{
Hastari* \\ E-mail: hastari052@gmail.com \\ *Program Studi Pendidikan Bahasa dan Sastra Indonesia, Universitas Maritim Raja Ali Haji, Kepulauan Riau, Indonesia
}

\begin{abstract}
Abstrak
Penelitian dilakukan bertujuan untuk memperoleh gambaran mengenai pengaruh pandemi Covid-19 terhadap efektivitas pembelajaran jarak jauh. Covid-19 atau coronavirus disease 2019 merupakan penyakit berbahaya, yang menular dengan sangat cepat. Virus Corona sudah menyebar hampir keseluruhan negara, salah satunya Indonesia. Oleh karena itu diterapkannya kebijakan, seperti isolasi, social distancing hingga dilakukan Pembatasan Sosial Berskala Besar (PSBB). Dalam memutuskan penyebaran virus Corona pemerintah memberlakukan Pembelajaran Jarak Jauh (PJJ). Pembelajaran jarak jauh belum bisa menggantikan pembelajaran secara tatap muka, karena pembelajaran tatap muka lebih efektif dibandingkan pembelajaran jarak jauh. Banyak siswa yang tidak menyukai pembelajaran jarak jauh yang dilakukan secara Online, sehingga siswa tidak dengan sungguh-sungguh melaksanakan pembelajaran dan tidak memahami materi yang disampaikan oleh guru, dan juga banyak siswa yang kesulitan mengakses jaringan internet. Jadi pandemi Covid-19 sangat berpengaruh pada efektivitas pembelajaran.
\end{abstract}

Kata kunci: Covid-19, Efektivitas, Pembelajaran Jarak Jauh.

\begin{abstract}
The research was conducted with the aim of obtaining an overview of the effect of the Covid-19 pandemic on the effectiveness of distance learning. Covid-19 or coronavirus disease 2019 is a dangerous disease, which spreads very quickly. The Corona virus has spread to almost all countries, one of which is Indonesia. Therefore, the implementation of policies, such as isolation, social distancing to carry out Large-Scale Social Restrictions (PSBB). In deciding the spread of the Corona virus, the government implemented Distance Learning (PJJ). Distance learning cannot replace faceto-face learning, because face-to-face learning is more effective than distance learning. Many students do not like distance learning that is done online, so students do not really carry out learning and do not understand the material presented by the teacher, and also many students have difficulty accessing the internet network. So the Covid-19 pandemic is very influential on the effectiveness of learning.
\end{abstract}

Keywords: Covid-19, Effectiveness, Distance Learning.

\section{PENDAHULUAN}

Dimulai dari wabah Covid-19 pertama kali muncul di kota Wuhan, tepatnya di Cina pada akhir Desember 2019. Wabah Covid-19 atau coronavirus disease 2019 merupakan penyakit berbahaya, yang menular dengan sangat cepat. Virus Corona ini adalah pandemi bagi masyarakat Indonesia, dan sekarang virus Corona semakin merajalela. Virus Corona bukan hanya penyakit biasa, namun virus ini bisa menyebabkan gangguan ringan dan berat pada sistem pernapasan, seperti infeksi paru-paru yang sangat berbahaya. Virus ini bisa menyerang siapa saja, seperti bayi, anak-anak, dan orang dewasa, meskipun begitu virus ini 
lebih banyak menyerang ke lansia yang lebih rentan, karena bagi siapa yang lemah menghadapi keadaan sekarang maka lebih mudah dan lebih cepat terinfeksi oleh virus Corona. Virus Corona ini telah menyebar hampir ke semua negara, termasuk Indonesia, dan sekarang tingkat kematian pun semakin meningkat. Oleh karena itu upaya untuk memutus mata rantai penyebaran virus Corona ini berbagai negara menetapkan kebijakan untuk memberlakukan lockdown sementara sebagai pencegahan penyebaran virus Corona (Fauzi, 2020: 122). Di negara Indonesia sendiri, untuk mengantisipasi penularan virus Corona ini pemerintah memberlakukan kebijakan, seperti isolasi, social distancing hingga dilakukan PSBB atau disebut juga dengan Pembatasan Sosial Berskala Besar (Siregar, H.S et al., 2020). PSBB ini dilakukan dalam rangka untuk menekan penyebaran virus Corona. Fauzi (2020: 122) dikarenakan Indonesia sedang melakukan PSBB, oleh karena itu semua kegiatan warga negara yang di lakukan di luar rumah harus dihentikan sementara waktu, sampai pandemi benar-benar menurun, tidak terkecuali pembelajaran di sekolah juga di hentikan untuk sementara waktu.

Beberapa pemerintah menerapkan kebijakan di setiap daerahnya dengan memberlakukan metode belajar dengan sistem PJJ atau disebut juga dengan Pembelajaran Jarak Jauh. Pembelajaran jarak jauh (PJJ) yaitu pembelajaran secara daring atau dalam jaringan yang dilakukan dengan memanfaatkan berbagai teknologi internet yang dilaksanakan secara Online. Di mana PJJ ini sangat dibutuhkan untuk masa sekarang yang sedang dilanda oleh pandemi Covid-19, yang memberikan dampak positif bagi warga negara Indonesia dalam memutuskan penyebaran virus Corona. PJJ tidak hanya memberi dampak positif namun juga memberi dampak negatif, yaitu bagi guru sangat sulit untuk menyampaikan materi-materi pembelajaran secara efektif di mana guru tidak bisa berkomunikasi secara langsung kepada siswanya dalam memberi pemahaman mengenai materi pembelajaran hingga siswa benar-benar memahami materi yang disampaikan. Namun bagi siswa sendiri, siswa juga sangat sulit untuk memahami materi melalu handphone atau laptop, mungkin dari karakter siswanya yang hanya bisa menerima materi pembelajaran secara langsung dijelaskan oleh gurunya. Di sini PJJ dalam dunia pendidikan sangat kurang efektif karena banyak sekali faktor-faktor atau kendala yang dihadapi guru maupun siswa, seperti kurangnya komunikasi antara guru dan siswa, sinyal yang kurang mendukung, dan kuota internet yang sangat mahal. Oleh karena itu, diperlukan berbagi solusi atau jalan keluar yang akan diambil pada masa sekarang ini khususnya pembelajaran jarak jauh. Hambatan dan solusi terhadap pembelajaran jarak jauh ini penting untuk di selesaikan, mengingat sistem pembelajaran ini akan digunakan selama pandemi Covid-19. Pembelajaran jarak jauh 
memberikan tantangan kepada semua jenjang pendidikan di seluruh Indonesia yang menerapkan sistem PJJ ini, yang mana mengharuskan setiap sekolah mempertahankan kelas tetap aktif meskipun pembelajaran tidak dilakukan secara langsung.

Dengan adanya wabah Covid-19 ini benar-benar menghambat kegiatan belajar mengajar yang biasanya dilakukan secara tatap muka. Meskipun begitu pembelajaran jarak jauh merupakan solusi dalam kegiatan pembelajaran selama pandemi, akan tetapi pembelajaran masih belum tentu bisa dilakukan secara efektif, di mana banyak kendala yang dihadapi terutama kemampuan dalam menguasai teknologi dan ekonomi peserta didik sendiri, dalam hal ini tidak semua peserta didik memiliki fasilitas-fasilitas yang bisa digunakan dalam pembelajaran jarak jauh, seperti handphone, laptop atau notebook, dan kuota internet yang cukup mahal bagi peserta didik yang kekurangan ekonominya, serta jaringan yang tidak mendukung khususnya bagi peserta didik yang berada di daerah terpencil atau pedesaan yang kesulitan dalam mengakses internet. Namun begitu kegiatan pembelajaran harus tetap berlanjut. Adapun media yang digunakan dalam pembelajaran jarak jauh yaitu, WhatsApp, Youtube, Zoom Meeting, Google Meet, dan Google Classroom. Materi yang diberikan pun bisa berupa video, bahan bacaan, dan bisa berupa PowerPoint. Namun begitu perlu dilakukan tindak lanjut atau langkah perbaikan agar pembelajaran secara daring dapat dilaksanakan secara efektivitas.

\section{HAKIKAT EFEKTIVITAS PEMBELAJARAN}

Menurut Miarso (Rohmawati, 2015: 16) efektivitas pembelajaran adalah satu standar mutu pendidikan yang sering kali diukur sesuai dengan tercapainya suatu tujuan pembelajaran, atau juga dapat diartikan sebagai ketepatan dalam mengelola suatu situasi tertentu. Menurut Supardi (Rohmawati, 2015: 16) pembelajaran efektif adalah suatu pembelajaran yang kombinasi dengan meliputi manusiawi, fasilitas, material, perlengkapan, dan prosedur yang diarahkan untuk dapat mengubah perilaku siswa ke arah yang lebih baik dan positif sesuai dengan potensi dan sesuai dengan perbedaan yang dimiliki masing-masing siswa dalam mencapai tujuan pembelajaran yang telah ditetapkan. Menurut Hamalik (Rohmawati, 2015: 16) pembelajaran yang efektif adalah pembelajaran yang dilakukan oleh siswa sendiri dan juga pembelajaran yang menyediakan kesempatan untuk siswa dalam melakukan aktivitas belajar seluas-luasnya. Artinya yaitu diharapkan dapat membantu siswa dalam memahami konsep pembelajaran yang telah ditentukan, agar dapat mencapai tujuan pembelajaran. 
Rohmawati (2015: 17) efektivitas pembelajaran merupakan suatu ukuran keberhasilan yang dilakukan melalui proses interaksi antara guru dengan siswa dalam mencapai tujuan pembelajaran. Efektivitas pembelajaran dapat dilihat dari proses pembelajaran yang sedang berlangsung, dari respons siswa terhadap pembelajaran dan penguasaan siswa terhadap materi pembelajaran. Dengan demikian dalam mencapai tujuan pembelajaran yang efektif dan efisien diperlukan suatu hubungan timbal balik antara guru dengan siswa dalam mencapai tujuan pembelajaran bersama, selain itu dalam mencapai tujuan pembelajaran juga harus menyesuaikan dengan kondisi atau lingkungan sekolah yang harus tertib dan disiplin, sarana dan prasarana juga harus mendukung kegiatan pembelajaran, serta media pembelajaran sesuai dengan yang dibutuhkan untuk mencapai tujuan pembelajaran.

\section{SARANA PENDUKUNG}

\section{a. Lokasi selama Pembelajaran Jarak Jauh}

Pembelajaran Jarak Jauh yang dilakukan di rumah adalah solusi terbaik dalam memutuskan penyebaran Covid-19. Namun ada beberapa siswa yang bosan melakukan pembelajaran di rumah, sehingga kurangnya minat siswa untuk belajar. Dampak tersebut sangat berpengaruh pada efektivitas pembelajaran pada umumnya. Namun begitu PJJ harus tetap dilakukan di dalam rumah sebagai bentuk upaya pencegahan terhadap wabah Covid-19.

\section{b. Media yang digunakan selama Pembelajaran Jarak Jauh}

Adapun platform yang digunakan dalam pembelajaran jarak jauh ini yaitu WhatsApp, Google Classroom, Edmodo, YouTube, Google Meet, Zoom Meeting dan sebagainya. Dalam penerapan ini dibutuhkan beberapa fasilitas-fasilitas dalam mengakses platform tersebut seperti, handphone, laptop atau notebook, bagi siswa yang memilikinya, namun bagi siswa yang tidak memiliki fasilitas tersebut sangat kesulitan dalam melakukan pembelajaran jarak jauh. Kegunaan WhatsApp dalam pembelajaran jarak jauh yaitu bisa mengirim pesan teks, pesan suara, gambar, video, dan berbagai file berbentuk Word atau PDF kepada semua anggota melalui WhatsApp Group (Kusuma \& Hamidah, 2020). Namun tidak hanya WhatsApp yang memiliki peran tersebut, Google Classroom, Edmodo, dan YouTube juga memiliki kegunaan bagi pendidik atau guru dalam mengembangkan pembelajaran yang kreatif. Diskusi dan transfer ilmu pengetahuan juga dilakukan secara face-to-face melalui berbagai platform seperti Zoom Meeting dan Google Meet. Platform tersebut sangat bermanfaat bagi pendidik dan peserta didik bisa bertemu dan bisa berinteraksi walaupun secara virtual dalam menyampaikan materi pembelajaran yang dilakukan melalui kegiatan presentasi (Wiranda \& Adri, 2019). 


\section{c. Pemahaman Siswa Terhadap Pembelajaran Jarak Jauh selama Pandemi Covid-19}

Banyak siswa yang merasa asing dengan pembelajaran jarak jauh ini, yang mana pembelajaran biasa dilakukan secara tatap muka. Kegiatan pembelajaran yang dilakukan secara tatap muka adalah kegiatan yang dilakukan sudah berjalan lama, sedangkan pembelajaran jarak jauh ini adalah suatu hal baru bagi siswa. Sehingga bagi siswa pembelajaran secara tatap muka dirasakan lebih nyaman, dibandingkan dengan pembelajaran jarak jauh yang dilakukan siswa sekarang ini. Untuk kelancaran pembelajaran jarak jauh tentunya membutuhkan upaya yang sungguh-sungguh dari siswa dan juga penyesuaian diri siswa terhadap pembelajaran jarak jauh ini. Namun tidak hanya itu siswa juga perlu beradaptasi terhadap kesigapan mental dan emosi yang stabil terhadap gangguan-gangguan yang dihadapinya. Namun sarana juga merupakan hal yang penting dalam pembelajaran jarak jauh, dan juga ketersediaan prasarana utamanya yaitu jaringan internet yang memadai, dan belum tentu dimiliki setiap daerah jaringan internet yang terjamin kualitasnya. Jaringan internet yang kurang di daerah terpencil atau pedesaan sangat menghambat siswa dalam mengikuti pembelajaran. Jadi pembelajaran jarak jauh dengan beberapa hambatan-hambatan yang dialami siswa membuat pemahaman siswa terhadap pembelajaran pada masa pandemi Covid-19 ini kurang memahami materi yang diberikan oleh guru. Sehingga kurangnya keefektifan dalam pembelajaran, karena pemahaman siswa terhadap materi masih kurang dan belum optimal.

\section{d. Hambatan Pembelajaran Jarak Jauh di saat Pandemi Covid-19}

Pembelajaran jarak jauh sangat banyak mengalami kendala-kendala atau hambatan yaitu jaringan internet yang kurang stabil, waktu siswa yang tidak sesuai, gangguan listrik, dan kehabisan kuota. Jadi pembelajaran Jarak Jauh yang dilakukan menggunakan jaringan internet, sangat memerlukan kuota internet untuk mengakses platform yang digunakan sebagai media pembelajaran. Dalam hal ini banyak siswa yang kekurangan ekonominya untuk membeli kuota setiap bulannya. Wabah Covid-19 tidak hanya berpengaruh pada dunia pendidikan, namun juga pada ekonomi masyarakat yang kini kerap menurun. Pembelajaran jarak jauh, tidak hanya kesulitan dalam kuota internet saja, tetapi juga kesulitan dalam mengakses internet bagi siswa yang tinggal di daerah terpencil atau pedesaan. Sehubungan dengan jaringan internet yang kurang stabil memiliki hambatan-hambatan antara lain, jaringan lemah, cuaca yang buruk seperti hujan, petir, gemuruh, yang membuat jaringan internet kurang stabil. Hambatan atau gangguan tersebut membuat kegiatan pembelajaran tidak bisa dilakukan secara efektif. 


\section{KESIMPULAN}

Dapat disimpulkan pengaruh pandemi Covid-19 terhadap efektivitas pembelajaran jarak jauh yaitu jaringan internet yang tidak stabil, sehingga membuat penjelasan dari guru mengenai materi pembelajaran tidak sepenuhnya bisa dipahami oleh siswa. Pembelajaran jarak jauh tidak hanya kurang efektif tetapi juga kurang menyenangkan bagi siswa, terutamanya bosan, dan tidak memiliki teman belajar. Jadi pembelajaran jarak jauh belum bisa menggantikan pembelajaran secara tatap muka, karena pembelajaran tatap muka lebih efektif dibandingkan pembelajaran jarak jauh. Namun pembelajaran jarak jauh dikatakan efektif apabila siswa benar-benar bisa memahami materi pembelajaran secara akurat, dalam hal ini yang dibutuhkan siswa tidak hanya bahan bacaan yang menarik namun juga memerlukan handphone yang memadai, kuota internet yang cukup, dan jaringan internet yang optimal. Dengan begitu barulah siswa bisa dengan sungguh-sungguh melaksanakan pembelajaran secara efektif.

\section{REFERENSI}

Fauzi, M. (2020). Strategi Pembelajaran Masa Pandemi Covid-19 Stit Al-Ibrohimy Bangkalan. Al-Ibrah, 5(2), http://ejournal.stital.ac.id/index.php/alibrah/article/view/104

Abidin, Z., Hudaya, A., \& Anjani, D. (2020). Efektivitas Pembelajaran Jarak Jauh pada Masa Pandemi Covid-19. Research and Development Journal Of Education, 1(1), 131-146. http://dx.doi.org/10.30998/rdje.v1i1.7659

Hatmo, S. H. D. (2021). Dampak Pandemi Covid-19 Terhadap Efektivitas Pembelajaran Jarak Jauh Secara Daring. Scholaria: Jurnal Pendidikan dan Kebudayaan, 11(2), 115122. https://ejournal.uksw.edu/scholaria/article/download/4222/1775

Widiyono, A. (2020). Efektifitas Perkuliahan Daring (Online) pada Mahasiswa PGSD di saat Pandemi Covid 19. Jurnal Pendidikan, 8(2), 169-177. https://doi.org/10.36232/pendidikan.v8i2.458

Herliandry, L. D., Nurhasanah, N., Suban, M. E., \& Kuswanto, H. (2020). Pembelajaran pada Masa Pandemi Covid-19. JTP-Jurnal Teknologi Pendidikan, 22(1), 65-70. https://doi.org/10.21009/jtp.v22i1.15286

Rohmawati, A. (2015). Efektivitas Pembelajaran. Jurnal Pendidikan Usia Dini, 9(1), 15-32. http://journal.unj.ac.id/unj/index.php/jpud/article/view/3491 


\section{*Data Penulis}

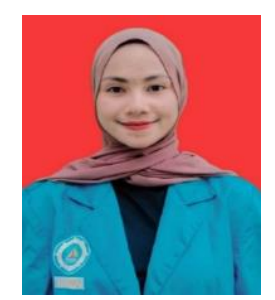

Hastari, lahir di Sebala, 05 Mei 2002. Tamatan SMA Negeri 2 Bunguran Timur tahun ajaran 2018/2019. Pada tahun 2019, Ia melanjutkan studi pada strata satu Program Studi Pendidikan Bahasa dan Sastra Indonesia FKIP Universitas Maritim Raja Ali Haji melalui jalur SNMPTN (Seleksi Nasional Masuk Perguruan Tinggi Negeri).

\section{Kontak:}

Hp/WA :-

Email : hastari052@gmail.com 